\title{
Analysis of RC Beams Repaired with CFRP Laminates
}

\author{
T.P.Meikandaan, M.Hemapriya, P.Mugilvani, R.Chitra
}

Abstract: Retrofitting materials like aluminum bars, steel overlays and glass fiber mixes has been utilized in the development field for a long time. Carbon fiber mixes are the ongoing expansion to the retrofitting materials. Trial and expository investigation have been done and compared.Total number of 6 shafts yet of which 3 are control bars and the other 3 pillars pre harmed $70 \%$ of extreme burden and after that enveloped by the base with CFRP laminates. Experimental examination completed by applying two-point load. Investigative examination by FEM specifically utilizing ABAQUS the predications utilizing the proposed diagnostic model are in great concurrence with the exploratory outcomes.

Key words: carbon fibre, epoxy, flexural, retrofitting, rehabilitation

\section{INTRODUCTION}

\section{A. General}

The current structures that are under seismic tremor activity, incompletely shafts are enduring harm. Then again, while deciding the presentation of the current structure during seismic arrangement that can happen, concerning as conceivable without expanding the mass of the structure, the hugeness of reinforcing the pillars turns out At each condition, therefore at either fix on fortify examinations, deciding the association between tech-nical fix systems and the shaft limit becomes a force to be reckoned with. Toward this path, thinks about are being finished by methods for being looked from changed perspective a heading. [1],[3],[5] The upkeep, recovery and overhauling of basic individuals, are maybe one of the most urgent issues in structural building applications. In addition, an enormous number of structures built in the past utilizing the more seasoned plan codes in various pieces of the world are fundamentally dangerous as indicated by the new plan codes. Since substitution of such inadequate components of structures acquires a colossal measure of open cash and time, reinforcing has turned into the satisfactory method for improving their heap conveying limit and expanding their administration lives. Framework rot

\section{Revised Manuscript Received on July 22, 2019}

T.P.Meikandaan,, Associate Professor, Department of Civil Engineering, Bharath Institute of Higher Education and Research, Chennai, Tamil Nadu

M.Hemapriya Assistant Professor, Department of Civil Engineering, Bharath Institute of Higher Education and Research, Chennai, Tamil Nadu

P.Mugilvani , Assistant Professor, Department of Civil Engineering, Bharath Institute of Higher Education and Research, Chennai, Tamil Nadu

R.Chitra, Assistant Professor, Department of Civil Engineering, Bharath Institute of Higher Education and Research, Chennai, Tamil Nadu brought about by untimely decay of structures and structures has lead to the examination of a few procedures for fixing or fortifying purposes. One of the difficulties in reinforcing of solid structures is determination of a fortifying strategy that will improve the quality and functionality of the structure while tending to confinements, for example, constructability, building tasks, and spending plan. Auxiliary fortifying might be required because of various circumstances.

\section{Finite Element Models}

The FEM adjustment concentrate included demonstrating a solid pillar with the measurements and properties. Because of the symmetry of cross-area of the solid bar and stacking, symmetry was used in the FEM; just one fourth of the bar was demonstrated.

\section{BEAM CASTING}

If there should arise an occurrence of a pillar or some other auxiliary part, the formwork is the shape, concrete is the material, it need not be hot and liquid as it is very plastic and streams, contingent upon the usefulness of the blend. The solid is permitted to harden, that is, it is permitted to set.This procedure of pouring cement in it's shape, that is, the formwork is called putting. Furthermore, the entire procedure inside and out is called throwing. [8],[ 10], [12]

\section{Mould Size \\ Height $=0.2 \mathrm{~m}$ \\ Length $=1.5 \mathrm{~m}$ \\ Width $=0.1 \mathrm{~m}$}

\author{
Volume Of Concrete (Number Of Beam 3) \\ $\mathrm{V}=\mathrm{l} * \mathrm{~h} * \mathrm{~W}$ \\ $\mathrm{V}=1.5 * 0.2 * 0.1 \mathrm{~V}$ \\ $=0.03 \mathrm{~m}^{\wedge} 3 \mathrm{~V}$ \\ $=0.03 * 3$ \\ $\mathrm{V}=0.09 \mathrm{~m}^{\wedge} 3$
}

\section{DETAIL ABOUT 20 CHANNEL DATA LOGGER}

\section{A . Introduction}

Measurement of physical parameters like load, pressure, linear dimensions, and vibration quantities such as acceleration, velocity frequency, and strain induced in structures, temperature, relative humidity ,ION concentration etc. are required to be made precisely and accurately for many process industries and control applications .most of these 
quantities were measured in earlier days purely by mechanical means and methods .the measurements were tedious and cumbersome to make and the results were usually available in visual from like a pointer needle moving over a graduated dial only. Hence the utilization of these measurements by way of feedback and process controls was achieved manually by means of skilled operators.

Strain gauge is one such instrument transducer which prevalently used now days for measurement purposes. These strain gauges are being used to sense load, it is termed as load cell - is called a pressure cell while sensing pressure cell while sensing pressure and is known as electrometer while used for sensing vibration. [13], [15], [ 17]

\section{B Load Frame}

A high solidness bolster structure against which the test powers can respond. The heap edge involves a base bar, two sections, and a moving crosshead.

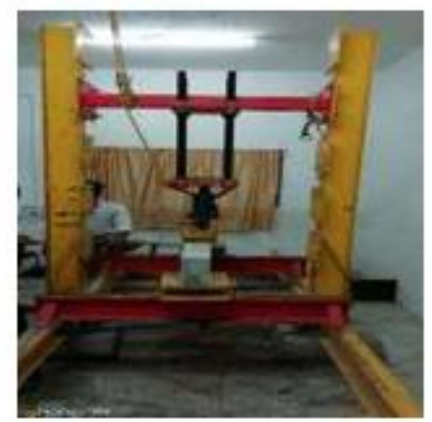

Figure 1 : Loading Frame

\section{Hydralic Jack}

A pressure driven jack is a gadget that is utilized to apply overwhelming burdens by applying a power by means of a water driven chamber. Water driven jacks lift burdens utilizing the power made by the weight in the chamber. [14], [ 16], [18]

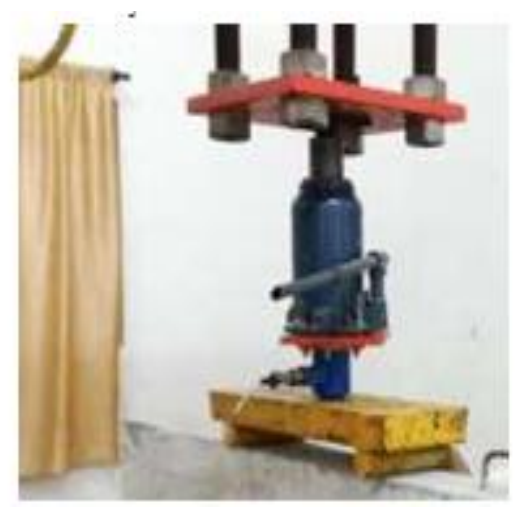

Figure 2 :Hydraulic Frame

\section{RESULT OF CONTROL BEAM}

\begin{tabular}{|c|c|c|c|c|}
\hline \multirow{2}{*}{$\begin{array}{c}\text { Lese } \\
\text { (Tompe) }\end{array}$} & \multicolumn{2}{|c|}{ Control Beam 1} & \multicolumn{2}{|c|}{ Control Besm 2} \\
\hline & 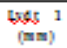 & $\begin{array}{l}\text { Lowdt } 2 \\
(\mathrm{~mm})\end{array}$ & $\underset{(\mathrm{mas})}{\log )^{1}}$ & $\begin{array}{l}\text { Lxds } 2 \\
\text { (mm) }\end{array}$ \\
\hline 0 & 0 & 0 & ${ }^{\circ}$ & 0 \\
\hline 01 & 0.7 & 0 & 0.6 & 0.1 \\
\hline 18 & 08 & 03 & 09 & 03 \\
\hline 13 & 1.1 & 0. & 1.1 & 09 \\
\hline 20 & 14 & 0.6 & 1.3 & 06 \\
\hline 3 & 18 & 10 & 1.7 & 09 \\
\hline 30 & 24 & 19 & 23 & 1.4 \\
\hline is & 28 & 1.7 & 28 & 16 \\
\hline 40 & 34 & 13 & 3.5 & 12 \\
\hline 43 & 38 & 2.7 & 3.7 & 26 \\
\hline 10 & 43 & 3.4 & 4.4 & 33 \\
\hline 19 & 18 & 48 & 5.7 & 48 \\
\hline 60 & 6.1 & 3.1 & 6.02 & 11 \\
\hline 61 & 63 & 11 & 6.3 & 19 \\
\hline 78 & 69 & $1 s$ & 6.6 & 13 \\
\hline 13 & 6.7 & 63 & 6.9 & 6.1 \\
\hline
\end{tabular}

\section{LOADVS DEFLECTION}

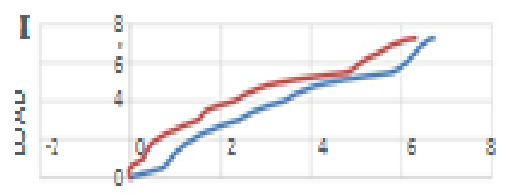

DEFLECTION $(\mathrm{mm})$

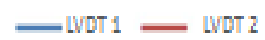

Figure 3 : Load Vs Deflection Graph For Control Beam SB-I

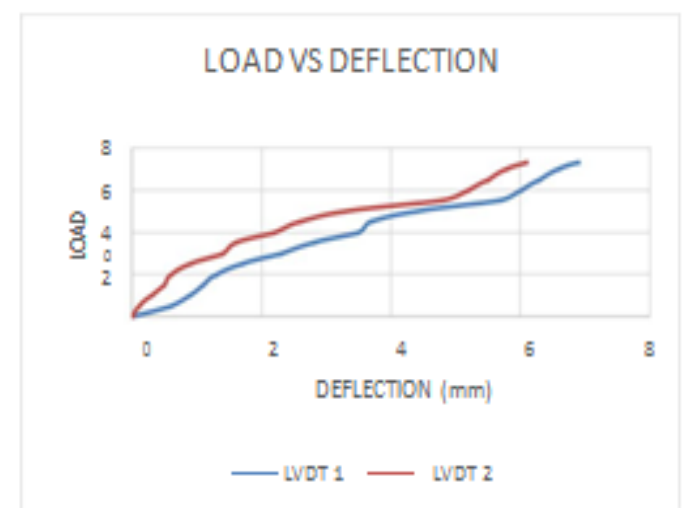

Figure 4 : Load Vs Deflection Graph For Control Beam SB-II 


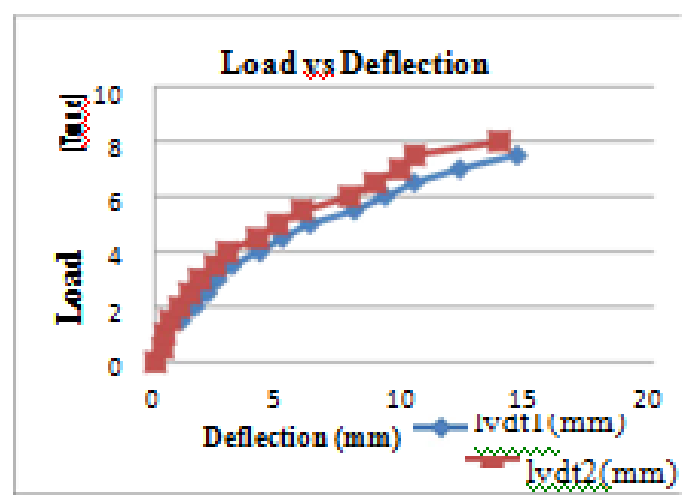

Figure 5: Load Vs Deflection Graph for Test Result Of CFRP Bottom Wrapping Multiple Layer For Predamaging (70\% For FB-I)

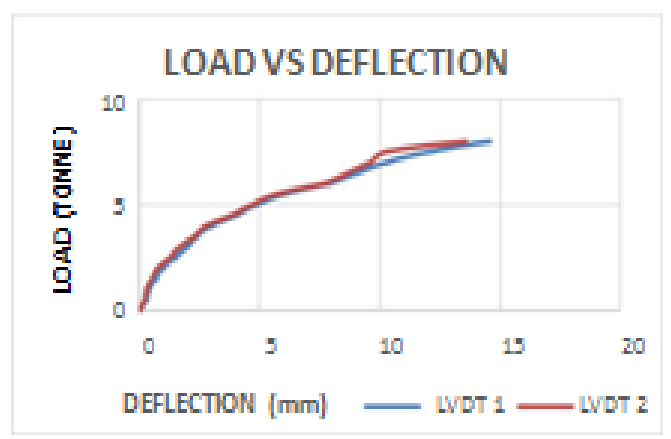

Figure 6: Load Vs Deflection Graph for Test Result Of CFRP Bottom Wrapping Multiple Layer For Predamaging (70\% For FB-II)

\section{ANALYTICAL INVESTIGATION}

\section{A. Software}

ABAQUS

ANSYS

\section{WRAPPING PATTERN OF CFRP}

CFRP sheets used in present investigation are fabric type E-carbon of grade 400 GSM. The sheets used were of bidirectional fibre orientation with tensile strength of $3450 \mathrm{~N} / \mathrm{mm} 2$.

\section{A Types of wrapping pattern for beam}

- Bottom Wrap- The underside of the beam wrapped with one and two layers of GFRP throughout the length and designated

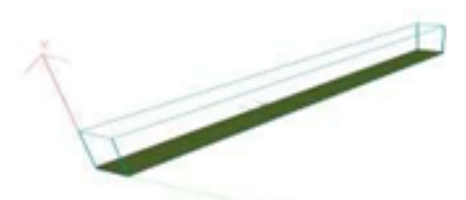

-U Wrap - The following are the different types of $U$ wraps: The beam wrapped with one and two layers on the underside and bottom half depth, throughout the length and designated. [26],[28],[30]

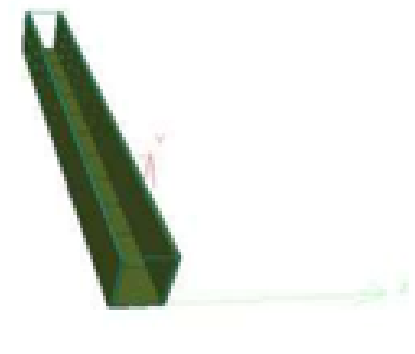

-Special Wap or Sides Wrap - The beam wrapped with one and two layers on the underside and bottom half depth, along a length of either ends of the beam and the remaining unwrapped portion of the beam was wrapped on the underside alone and designated.

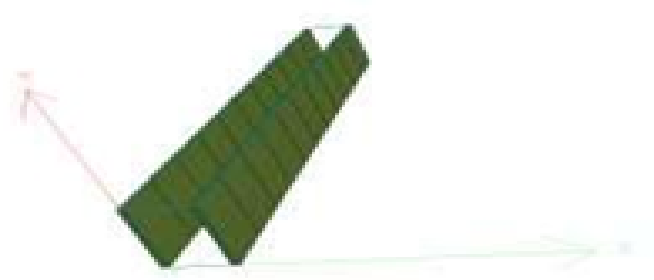

VII. ANALYSIS

One of the targets of this examination is to build up a limited component model speaking to the R.C.C. pillars to examine the heap avoidance conduct of wrapped and unwrapped examples. Numerical examinations were performed utilizing the ABAQUS suite limited component program to foresee a definitive stacking limit of rectangular fortified solid bars reinforced by CFRP composites, Linear material conduct, as it identifies with steel strengthening bars, plain concrete and fiber-fortified polymer were reenacted utilizing fitting constitutive models. The impacts of wrapping with CFRP on a definitive quality of the bars were researched. [20],[ 22], [24]

\section{BEAM MODELLING}

\section{A. Modelling Of Concrete Element}

In ABAQUS the concrete element was modelled using 3D solipelement. 


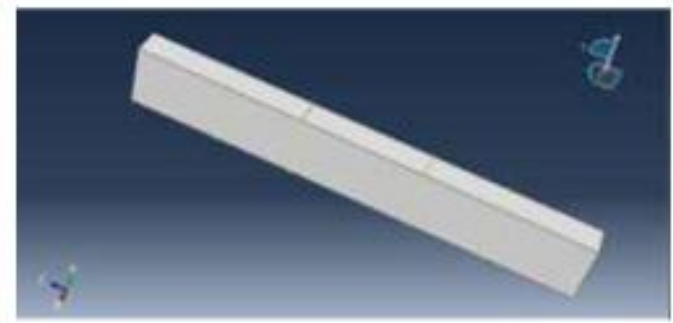

\section{B. Modelling Of Steel Reinforcement Element}

The steel reinforcement bar element was modelled using 3D wire element

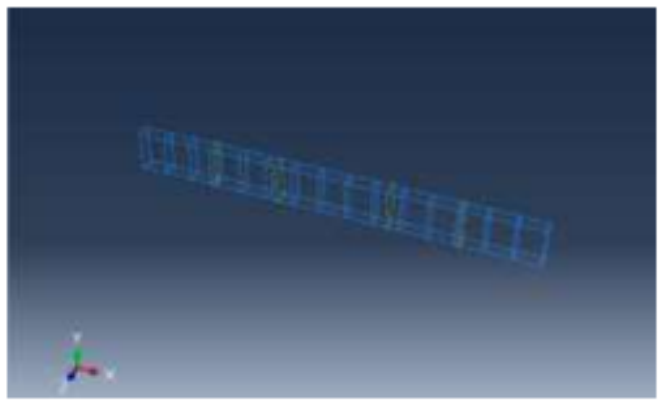

C. Assemblies modelling of Concrete beam and Steel Reinforcement

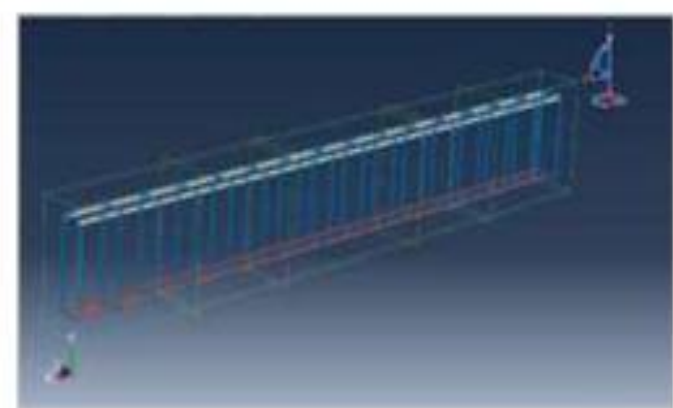

D. Finite elements meshing of normal strengthened beam

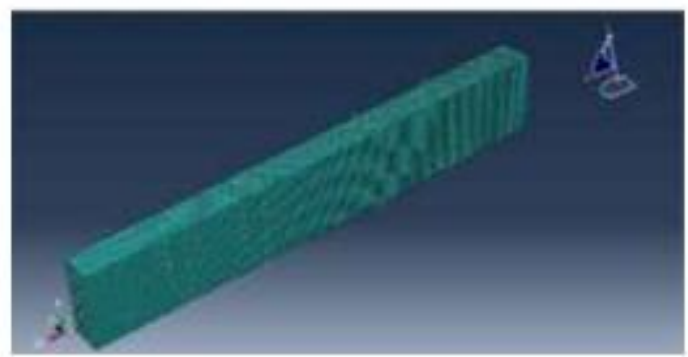

E. Modelling of boundary condition and loading applied
The model was simply supported with boundary conditions of hinged and roller supports on either sides with 2-point loading on top on the beam.

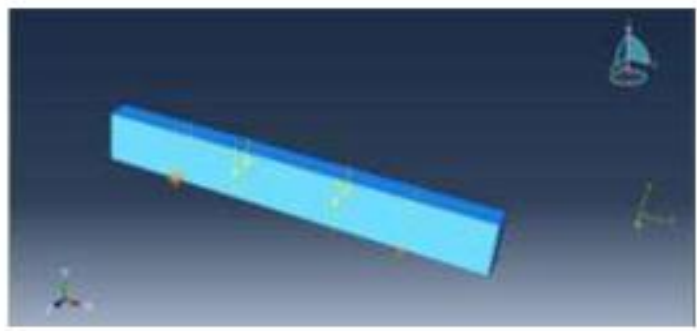

F. Deformation pattern of normal beam at ultimate load

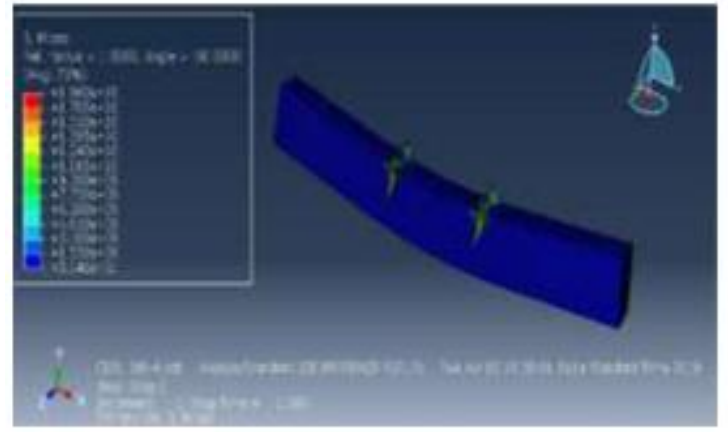

A. Modelling procedure of a beam damaged at $70 \%$ of the ultimate load

The modelling of the beam and the reinforcement is same as the that of the control beam represented above.

\section{Modelling of boundary condition and loading applied}

The beam has been given the same boundary condition which was given to the control beam and the load which is being provided on the beam below is $70 \%$ of the ultimate load at which the control beam failed. [32],[34],[36]

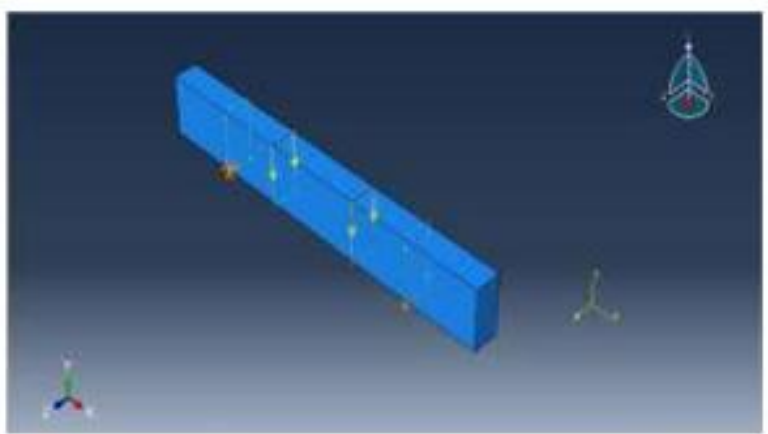

2. Deformation Pattern of normal Beam pattern at $70 \%$ of the Ultimate load 


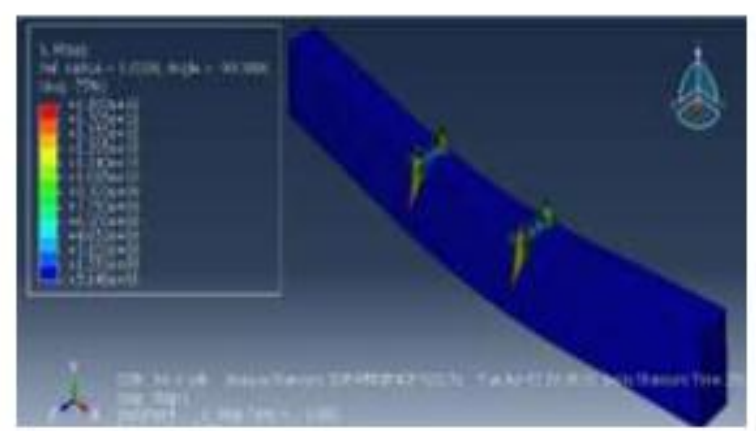

B. Modelling procedure of the $\mathbf{7 0 \%}$ pre-damaged beam wrapped with CFRP composite laminate

The modelling of the concrete beam and the steel reinforcement is same as that of the control beam

1. Modelling of adhesive/ epoxy

Modelling of adhesive was done on the basis of the specific properties of the material using 3D solid element.

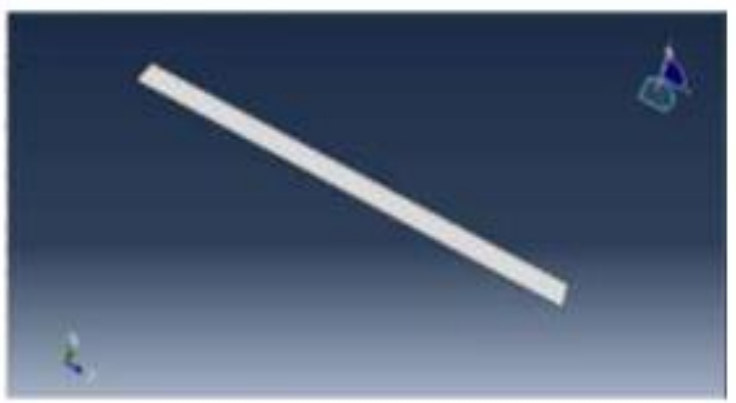

2. Modelling of CFRP composite laminate

Modelling of CFRP composite laminate was done using 3D solid element

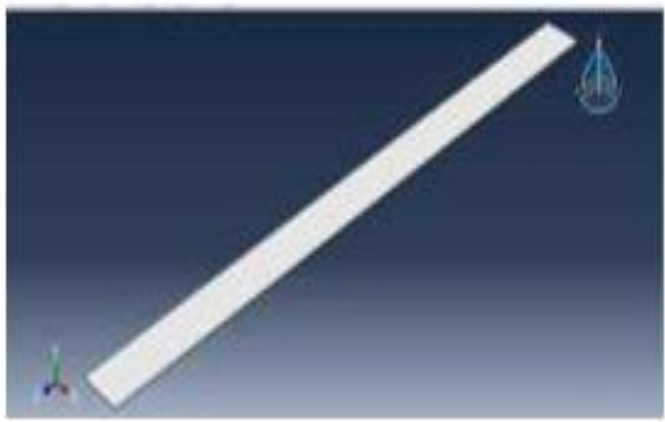

3. Assembly of concrete beam, reinforcement details, adhesive and the CFRP laminate

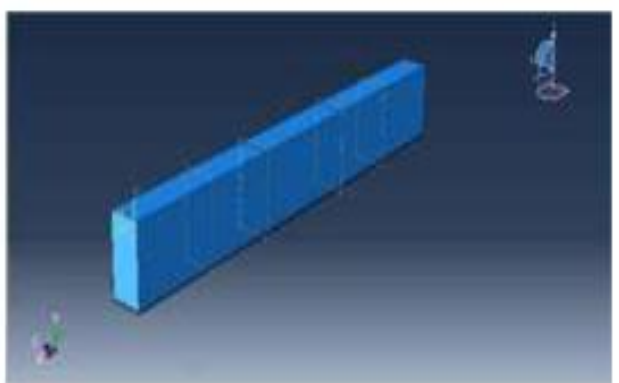

4. Modelling Of Boundary Conditions And Load Applied Simply Supported Just Like Control Beam

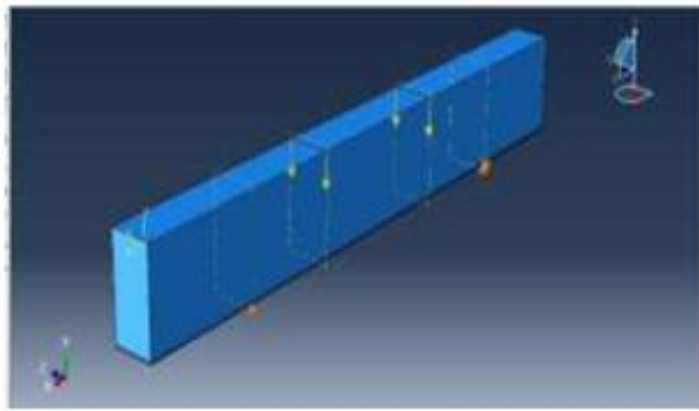

5. Deformation pattern of normal beam wrapped with CFRP composite laminate

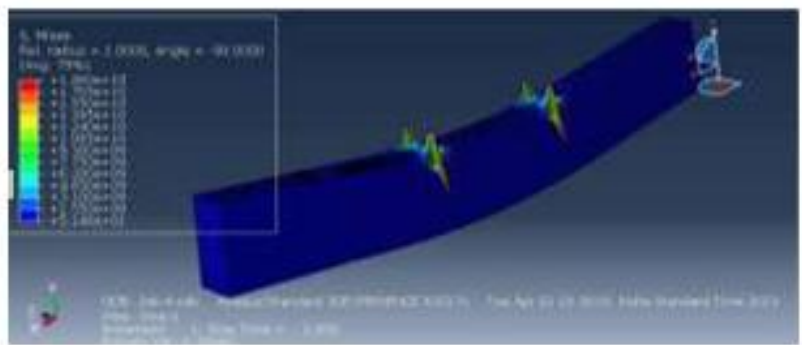

6. Deformation Pattern Of Fully Wrapped Flexure Strengthened Beam Model At Ultimate Load

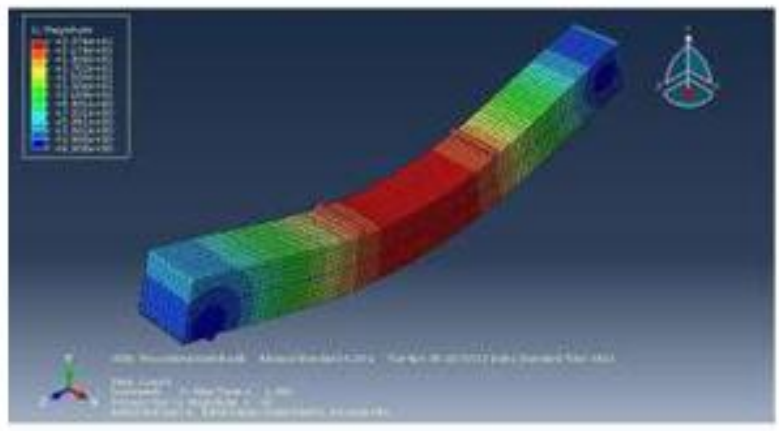

7. Comparison Of Analytical And Experimental Load Deflection Shear Beam 


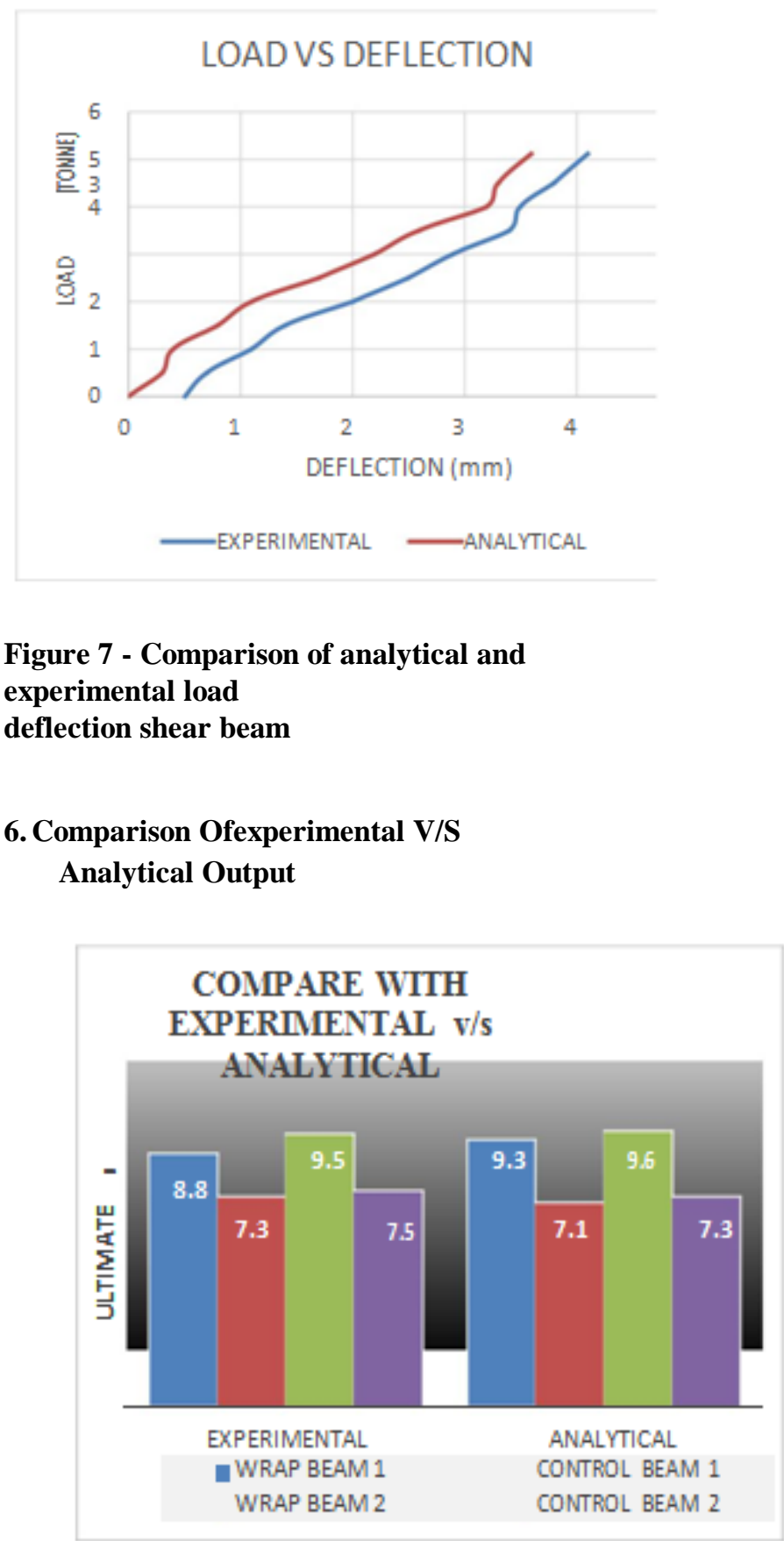

\section{CONCLUSION}

Based on the experimental and analytical results the following conclusions has been made.

The predictions using the suggested analytical model are in good agreement with the experimental results.

The flexural strength of the bottom wrapped beams is higher than the control beams.

The peak value of the load of the strengthened beams is around $28 \%$ higher than the control beams. [38],[40],[42]

\section{REFERENCES}

1. Iyappan L., Dayakar P., Identification of landslide prone zone for coonoortalukusing spatial technology, International Journal of Applied Engineering Research,V-9,I-22,PP-5724-5732,Y-2014.

2. Kumar J., Sathish Kumar K., Dayakar P.,Effect of microsilica on high strength concrete, International Journal of Applied Engineering Research,V-9,I-22,PP-5427-5432,Y-2014.

3. Dayakar P., Vijay Ruthrapathi G., Prakesh J., Management of bio-medical waste, International Journal of Applied Engineering Research,V-9,I-22,PP-5518-5526,Y-2014.

4. Swaminathan N., Dayakar P., Resource optimization in construction project, International Journal of Applied Engineering Research,V-9,I-22,PP-5546-5551,Y-2014.

5. Venkat Raman K., Dayakar P., Raju K.V.B.,An experimental study on effect of cone diameters in penetration test on sandy soil, International Journal of Civil Engineering and Technology,V-8,I-8,PP-1581-1588,Y-2017.

6. Saritha B., Chockalingam M.P.,Photodradation of malachite green DYE using TIO2/activated carbon composite, International Journal of Civil Engineering and Technology,V-8,I-8,PP-156-163,Y-2017

7. Shendge R.B., Chockalingam M.P., Saritha B., Ambica A.,Swat modelling for sediment yield: A case study of Ujjani reservoir in Maharashtra, India,International Journal of Civil Engineering and Technology,V-9,I-1,PP-245-252,Y-2018

8. Chockalingam M.P., Balamurgan V.,Modernisation of an existing urban road-sector in Chennai, a case study report,International Journal of Civil Engineering and Technology,V-8,I-8,PP-1457-1467,Y-2017

9. Saritha B., Chockalingam M.P.,Adsorption study on removal of basic dye by modified coconut shell adsorbent, International Journal of Civil Engineering and Technology,V-8,I-8,PP-1370-1374,Y-2017

10.Saritha B., Chockalingam M.P.,Adsorptive removal of heavy metal chromium from aqueous medium using modified natural adsorbent,International Journal of Civil Engineering and Technology,V-8,I-8,PP-1382-1387,Y-2017

11.Chockalingam M.P., Palanivelraja S.,Retrospective analysis of a theoretical model used for forecasting future air quality near the north Chennai thermal power plant,International Journal of Civil Engineering and Technology,V-8,I-8,PP-1457-1467,Y-2017

12.Saritha B., Chockalingam M.P.,Photodegradation of methylene blue dye in aqueous medium by $\mathrm{Fe}-\mathrm{AC} / \mathrm{TiO} 2$ Composite,Nature Environment and

Pollution

Technology,V-17,I-4,PP-1259-1265,Y-2018

13. Shendge R.B., Chockalingam M.P., Kaviya B., Ambica A.,Estimates of potential evapotranspiration rates by three methods in upper Bhima Basin, In Maharashtra, India,International Journal of Civil Engineering and Technology,V-9,I-2,PP-475-480,Y-2018

14.Shendge R.B., Chockalingam M.P.,The soil and water assessment tool for Ujjani Reservoir,International Journal of Mechanical Engineering and Technology,V-9,I-2,PP-354-359,Y-2018

15.Shendge R.B., Chockalingam M.P.,A review on soil and water assessment tool,International Journal of Mechanical Engineering and Technology,V-9,I-2,PP-347-353,Y-2018

16.Sachithanandam P., Meikandaan T.P., Srividya T.,Steel framed multi storey residential building analysis and design,International Journal of Applied Engineering Research,V-9,I-22,PP-5527-5529,Y-2014

17.Meikandaan T.P., Ramachandra Murthy A.,Study of damaged RC beams repaired by bonding of CFRP laminates,International Journal of Civil Engineering and Technology,V-8,I-2,PP-470-486,Y-2017

18.Meikandaan T.P., Ramachandra Murthy A.,Retrofittng of reinforced concrete beams using GFRP overlays,International Journal of Civil Engineering and Technology,V-8,I-2,PP-423-439,Y-2017

19.Meikandaan T.P., Ramachandra Murthy A.,Flexural behaviour of RC beam wrapped with GFRP sheets, International Journal of Civil Engineering and Technology,V-8,I-2,PP-452-469,Y-2017

20.Meikandaan T.P., Murthy A.R.,Experimental study on strengthening of rc beams using glass Fiber,International Journal of Civil Engineering and Technology,V-9,I-11,PP-959-965,Y-2018

21.Meikandaan T.P., Hemapriya M.,Use of glass FRP sheets as external flexural reinforcement in RCC Beam,International Journal of Civi Engineering and Technology,V-8,I-8,PP-1485-1501,Y-2017

22.Saraswathy R., Saritha B.,Planning of integrated satellite township at Thirumazhisai,International Journal of Applied Engineering Research,V-9,I-22,PP-5558-5560,Y-2014

23.Saritha B., Ilayaraja K., Eqyaabal Z., Geo textiles and geo synthetics for soil reinforcement,International Journal of Applied Engineering Research,V-9,I-22,PP-5533-5536,Y-2014

24.Ambica A., Saritha B., Changring G., Singh N B., Rajen M., Salman Md.,Analysis of groundwater quality in and around Tambaram taluk, 
Kancheepuram district,International Journal of Civil Engineering and Technology,V-8,I-8,PP-1362-1369,Y-2017

25. Arunya A., Sarayu K., Ramachandra Murthy A., Iyer N.R.,Enhancement of durability properties of bioconcrete incorporated with nano silica,International Journal of Civil Engineering and Technology,V-8,I-8,PP-1388-1394,Y-2017

26.Ilayaraja K., Krishnamurthy R.R., Jayaprakash M., Velmurugan P.M., Muthuraj S.,Characterization of the 26 December 2004 tsunami deposits in Andaman Islands (Bay of Bengal, India),Environmental Earth Sciences,V-66,I-8,PP-2459-2476,Y-2012

27.Ilayaraja K.,Morphometric parameters of micro watershed in Paravanar sub-basin, Cuddalore District,International Journal of Civil Engineering and Technology,V-8,I-8,PP-1444-1449,Y-2017

28.Ilayaraja K., Singh R.K., Rana N., Chauhan R., Sutradhar N.,Site suitability assessment for residential areas in south Chennai region using remote sensing and GIS techniques,International Journal of Civil Engineering and Technology,V-8,I-8,PP-1468-1475,Y-2017

29.Ilayaraja K., Reza W., Kumar V., Paul S., Chowdhary R.,Estimation of land surface temperature of Chennai metropolitan area using Landsat images,International Journal of Civil Engineering and Technology, V-8,I-8,PP-1450-1456,Y-2017

30.Chitra R.,Experimental study on beam using steel fiber and latex,International Journal of Civil Engineering and Technology,V-8,I-8,PP-1395-1403,Y-2017

31.Chitra R.,Analysis of traffic and management at Kovilambakkam intersection,International Journal of Civil Engineering and Technology,V-8,I-8,PP-1433-1443,Y-2017

32.Aswathy M.,Experimental study on light weight foamed concrete,International Journal of Civil Engineering and Technology,V-8,I-8,PP-1404-1412,Y-2017

33. Aswathy M.,Wastewater treatment using constructed wetland with water lettuce (Eichornia Crasipies),International Journal of Civil Engineering and Technology,V-8,I-8,PP-1413-1421,Y-2017

34.Kiruthiga K., Anandh K.S., Gunasekaran K, Assessment of influencing factors on improving effectiveness and productivity of construction engineers, 2015, International Journal of Applied Engineering Research, V - 10,I -17,p -13849-13854.

\section{AUTHORS PROFILE}

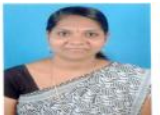

Thendral Sundarrajan, Assistant Professor, Department of Computer Science \& Engineering, Bharath Institute of Higher Education and Research, Chennai, India

A.Arunya, Associate Professor, Department of Computer Science \& Engineering, Bharath Institute of Higher Education and Research, Chennai, India

R.Chitra, Assistant Professor, Department of Computer Science \& Engineering, Bharath Institute of Higher Education and Research, Chennai, India 